\title{
Impact of Cement Dust on Physical and Chemical Nutrients Properties of Forest Topsoil
}

\section{${ }^{1}$ ADEBIYI, AP; ${ }^{1}$ ADIGUN, HO; ${ }^{1}$ LAWAL, K. J; *2SALAMI, KD; ${ }^{1}$ ADEKUNLE, VAJ; ${ }^{1}$ OYELAKIN, JA}

\author{
${ }^{I}$ Department of Forestry and Wood Technology, Federal University of Technology Akure, Nigeria \\ ${ }^{* 2}$ Department of Forestry and Wildlife Management, Federal University Dutse, Dutse, Jigawa State, Nigeria. \\ *Corresponding Author Email: foristsalam@yahoo.com; Tel: +2347034294371
}

\begin{abstract}
The study examined the impact of Cement dust on physical and chemical nutrients properties of forest topsoil in close proximity to a major private cement industry in Obajana, Kogi State, Nigeria using standard methods by collecting Topsoil samples for physical and chemical properties analyses which are particle size, moisture content, $\mathrm{pH}$, carbon, nitrogen, phosphorus, potassium, sodium, calcium, magnesium, cation exchange capacity and organic matter.Data revealed a strong influence of the particulate pollutants on the forest topsoil in close proximity to the Cement factory. It was observed that the soil properties; moisture content and soil $\mathrm{pH}$ varied at distances away from the factory. The result showed that the Cement dust particles entering the soil increased the $\mathrm{pH}$ of the soil, it more alkaline. The highest $\mathrm{pH}(6.03)$ was observed from hundred and fifty meters sample indicating the highest particulate pollution. There were also variations in the other soil nutrient properties; carbon, nitrogen, phosphorus, potassium, sodium, calcium, magnesium, cation exchange capacity and organic matter arising from the effect of cement dust. High organic matter content was recorded in the location samples compared with the control sample. This is attributed to the addition of cement dust to the soils, resulting in improved organic-matter cycling and plant growth. The result also showed that the chemical properties; organic carbon (OC), organic matter $(\mathrm{OM})$, phosphorus (P), potassium $(\mathrm{K})$, sodium $(\mathrm{Na})$, calcium $(\mathrm{Ca})$ and magnesium $(\mathrm{Mg})$ are significantly higher in the study areas than the control. The study therefore concludes that the emission of cement dust on the forest stands over the years was found to have significantly affected the topsoil properties.
\end{abstract}

\section{DOI: $\underline{\text { https://dx.doi.org/10.4314/jasem.v25i5.2 }}$}

Copyright: Copyright $\left({ }^{\circ} 2021\right.$ Adebiyi et al. This is an open access article distributed under the Creative Commons Attribution License (CCL), which permits unrestricted use, distribution, and reproduction in any medium, provided the original work is properly cited.

Dates: Received: 20 March 2021; Revised: 27 April 2021; Accepted: 07 May 2021

Keywords: Impact, Cement Dust, Physical and Chemical Nutrients and Properties of Forest Topsoil

Generally, the natural environment is made up of air, water and soil. The release of emission of industrial waste such as cement dust into anyone of the components of the environment causes pollution. The presence of pollutants in the environment tampers with the natural environmental media (air, water, and land) thus, affecting plant, animal and human lives (Vhahangweli and Khathutshelo, (2018).Cement dust is one of the industrial wastes that affect the soil properties. Cement manufacturing includes mining and quarrying of raw materials, which are principally oxides and carbonates of metals. It also involves grinding the raw materials into fine particles, such as limestone, shale, sand, clay, iron ore, and fly ash, and mixing them in appropriate proportions. Mild heating is applied to drive off any water and carbon dioxide available in the limestone (Inibabi et al., 2013). It is a very dusty and energy-consuming process, constituting a very serious source of air pollution. Cement dusts influence the ecosystems including soil and plants, cause the imbalances in soil nutrients and reduce biodiversity (Gheorghe, and Barbu, 2010).
Because of its high carbonate content, the dusts tend to be highly alkaline. The dust particles discharged into the atmosphere during grinding, crushing, and blending of the raw materials in the cement factory eventually reach the soil as dissolved substances during rains as fallouts (Russell, 2007). Once in the soil, the metals contained in the dust undergo reactions that affect the chemical, physical, and biological properties of the soil. Pathak and Khan, (1994) reported that treating the soil with one of the raw materials of cement (fly ash) had effect on the physical and chemical as well as the biological properties of soil. They determined that the water holding capacity, electrical conductivity, and $\mathrm{pH}$ of the soil were affected. The fly ash also neutralized the acidity of the soil by raising the soil $\mathrm{pH}$. Its application enhanced the metabolic rates and growth and increased the photosynthetic pigments of crops. However, the ash contains toxic substances, such as dibenzofuran and bibenzo-p-dioxane mixtures which may interfere with the normal physiological development of agricultural crops (Heerden et al., 2007). Brigden and Santillo 
(1987) also discovered the presence of nickel, arsenic, cadmium, chromium, lead, selenium, zinc, and copper in fly ash. Deposition of industrial wastes on soils has both advantages and disadvantages. Hence, this study aimed at examining the effect of cement dust on the physiochemical properties of forest topsoil around private cement factory at Obajana in Kogi State, Nigeria.

\section{MATERIAL AND METHODS}

Study area: The study was carried out at the forest stands in the surroundings of private cement factory, Obajana, Kogi State, Nigeria. It is on a latitude $7.92635^{\circ} \mathrm{N}$ and longitude $6.41456^{\circ} \mathrm{E}$ with elevation of $41 \mathrm{~m}$.

Data collection: Soil samples in the vicinity of the cement factory where the dust is visually evident to fall predominantly were collected to obtain maximum dust particulates and in the adjoining forest. A $500 \mathrm{x}$ $500 \mathrm{~m}$ plot was established in a forest at $50 \mathrm{~m}$ distance to the cement factory. The starting point coordinate is $+07.92736^{\circ} \mathrm{N},+006.41306^{\circ} \mathrm{E}$ and elevation of $209 \mathrm{~m}$ and ending point coordinate is $+07.92772^{\circ} \mathrm{N}$, $+006.41069^{\circ} \mathrm{E}$ and elevation of $228 \mathrm{~m}$. A $100 \times 100 \mathrm{~m}$ plot was also established in an adjoining forest to serve as control. A ten small quadrant of $25 \times 25 \mathrm{~m}$ was laid inside the $500 \times 500 \mathrm{~m}$ and a four small quadrant of $25 \mathrm{~m} \times 25 \mathrm{~m}$ was laid in $100 \times 100$ mestablished plots respectively. A small quadrant of $5 \times 5 \mathrm{~m}$ was laid inside each of the $25 \times 25 \mathrm{~m}$ established plots. Topsoil samples were collected along the diagonal of each quadrant using the soil auger. The soil samples were collected in five points on each quadrant diagonally with soil auger at the depth of $0-10 \mathrm{~cm}$ and bulked. The samples were air dried and sieved with a $2 \mathrm{~mm}$ sieve for the laboratory analysis. All samples were subjected to the physical and chemical laboratory analysis.

Determination of the physicochemical characteristics of the soil sample: The soil mechanical analysis and moisture content were established by the hydrometer method of Ibitoye (2008), while the soil pH was determined according to IITA, (1979). The organic carbon was established by the standard method of AOAC, (1999). The total Nitrogen and available Phosphorus content of the soil were evaluated by the micro Kjeldahl digestion and distillation method as described by Biey et al.,(2000) and Deboszet al., (2002) respectively. The exchangeable bases ( $\mathrm{Na}, \mathrm{K}$, $\mathrm{Ca}$ and $\mathrm{Mg}$ ) were estimated according to Barker, (2001) and AOAC, (1999). Emission against concentration was recorded both in standard and sample solution using flame photometer for $\mathrm{Ca}$ and $\mathrm{Mg}$ while $\mathrm{K}$ and $\mathrm{Na}$ were read off using a flame photometer. Cation Exchange Capacity (CEC) was determined by ammonia saturation method coined by Ibitoye, 2002) while Organic matter was determined according to Walkey and Black, (1934) methods.

Experimental design and data analysis: The experiment was laid out in a Randomized Complete Block Design (RCBD). Transects formed the block while the distances are another source of variation and the soil nutrients are the treatment. The statistical data was carried out based on the data obtained. The results from all laboratory experiments were subjected to ANOVA test for significant difference in their nutrient contents. All analyses were carried out using SPSS software.

$Y_{i j k}=\mu+B_{i}+T_{j}+\varepsilon_{i j k}$

Where $\mathrm{Y}_{\mathrm{ijk}}=$ individual observation; $\mu=$ general mean; $\mathrm{B}_{\mathrm{i}}=$ effect of Block (soil depth); $\mathrm{T}_{\mathrm{j}}=$ effect of treatment; $\varepsilon_{\mathrm{ijk}}=$ experimental error

\section{RESULTS AND DISCUSSION}

Soil Physical Analysis: Table 1 showed the result of the physical properties of the topsoil in each transect and the control. The result showed higher percentage of sand in the three locations as it ranges from 98.42 99.81. The highest percentage of sand $(99.81 \pm 1.57)$ in the topsoil is recorded in control. This is followed by the topsoil from transect $1(98.42 \pm 2.8)$ and the least percentage of sand in the topsoil is from transect 2 $(98.41 \pm 2.78)$. The percentage proportion of clay is found in transect 1 and transect 2 . The clay contents are $0.143 \pm 0.03$ and $0.142 \pm 0.03$ respectively. Control has the least percentage proportion of clay $(0.14 \pm 0.03)$. The result of the percentage proportion of silt content in the topsoil of transect 1 and transect 2 is the same $1.44 \pm 2.80$. The result also revealed the moisture content present in topsoil of the locations. The results showed that the topsoil from transect 2 has the highest percentage of moisture content $(8.668 \pm 2.63)$. This is followed by the moisture content in the topsoil from transect $1(6.692 \pm 7.72)$ and control has the least percentage of moisture content $(4.83 \pm 1.570)$.

Soil Chemical Analysis: Table 2 showed the result of the chemical nutrient properties of forest topsoil from transect 1, transect 2, and control. The chemical properties are as follows: For Transect 1, the mean $\mathrm{pH}$ is 4.36 at fifty meters to the cement factory while the Sodium $(\mathrm{Na})$, Potassium $(\mathrm{K})$ and Magnesium $(\mathrm{Mg})$ are $13.04 \mathrm{ppm}, 37.44 \mathrm{ppm}$ and $0.85 \mathrm{cMol} / \mathrm{kg}$ respectively. At this point also, the amount of calcium (Ca) is $1.56 \mathrm{ppm}$ and the Phosphorus is $12.83 \mathrm{ppm}$. The level of the Nitrogen $(\mathrm{N})$, Organic carbon, and Organic 
matter are $0.42 \%, 3.55 \%$, and $6.12 \%$ respectively. Seventy meters away from the factory, the forest topsoil has the following nutrients mean values: the mean $\mathrm{pH}$ is 5.18 while the Sodium $(\mathrm{Na})$, Potassium (K) and Magnesium $(\mathrm{Mg})$ are $12.17 \mathrm{ppm}, 31.03 \mathrm{ppm}$ and $0.40 \mathrm{cMol} / \mathrm{kg}$ respectively.

Table 1: Physical Properties of Forest Topsoil

\begin{tabular}{|c|c|c|c|c|}
\hline Location & Clay $(\%)$ & Silt (\%) & Sand $(\%)$ & Moisture (\%) \\
\hline Transect 1 & $0.143 \pm 0.029$ & $1.44 \pm 2.795$ & $98.42 \pm 2.79$ & $6.692 \pm 7.72$ \\
\hline Transect 2 & $0.142 \pm 0.032$ & $1.44 \pm 2.80$ & $98.41 \pm 2.784$ & $8.668 \pm 2.631$ \\
\hline Control & $0.14 \pm 0.032$ & $0.055 \pm 0.033$ & $99.81 \pm 1.570$ & $4.83 \pm 1.570$ \\
\hline
\end{tabular}

At this point also, the amount of calcium $(\mathrm{Ca})$ is $3.12 \mathrm{ppm}$ and the Phosphorus is 25.90ppm. However, the level of Nitrogen $(\mathrm{N})$ at this point is $0.49 \%$, the Carbon (C) is $1.58 \%$, the Organic matter (OM) is $2.72 \%$ and $\mathrm{CEC}$ is $28 \mathrm{cMol} / \mathrm{kg}$. Ninety meters away from the factory, the forest topsoil has the following nutrients mean values: the mean $\mathrm{pH}$ is 5.94 while the Sodium (Na), Potassium (K) and Magnesium $(\mathrm{Mg})$ are $10.00 \mathrm{ppm}, 9.49 \mathrm{ppm}$ and $0.64 \mathrm{cMol} / \mathrm{kg}$ respectively. At this point also, the amount of calcium $(\mathrm{Ca})$ is $3.60 \mathrm{ppm}$ and the Phosphorus is $15.24 \mathrm{ppm}$. However, the level of Nitrogen $(\mathrm{N})$ at this point is $0.56 \%$, the Carbon $(\mathrm{C})$ is $2.36 \%$, the Organic matter (OM) is $4.07 \%$ and CEC is $21 \mathrm{cMol} / \mathrm{kg}$. Hundred and ten meters away from the factory, the forest topsoil has the following nutrients mean values: the mean $\mathrm{pH}$ is 5.98 while the Sodium $(\mathrm{Na})$, Potassium $(\mathrm{K})$ and Magnesium $(\mathrm{Mg})$ are $11.30 \mathrm{ppm}, 30.26 \mathrm{ppm}$ and $1.24 \mathrm{cMol} / \mathrm{kg}$ respectively. At this point also, the amount of calcium (Ca) is $1.72 \mathrm{ppm}$ and the Phosphorus is $10.58 \mathrm{ppm}$. However, the level of Nitrogen $(\mathrm{N})$ at this point is $0.42 \%$, the Carbon (C) is $3.82 \%$, the Organic matter (OM) is $6.59 \%$ and $\mathrm{CEC}$ is $21 \mathrm{cMol} / \mathrm{kg}$. Hundred and thirty meters away from the factory, the forest topsoil has the following nutrients mean values: the mean $\mathrm{pH}$ is 5.54 while the Sodium (Na), Potassium (K) and Magnesium (Mg) are 11.74ppm, 23.08ppm and $0.44 \mathrm{cMol} / \mathrm{kg}$ respectively. At this point also, the amount of calcium (Ca) is $1.48 \mathrm{ppm}$ and the Phosphorus is $11.20 \mathrm{ppm}$. However, the level of Nitrogen $(\mathrm{N})$ at this point is $0.56 \%$, the Carbon $(\mathrm{C})$ is $2.29 \%$, the Organic matter (OM) is $3.95 \%$ and CEC is $22.40 \mathrm{cMol} / \mathrm{kg}$. Hundred and fifty meters away from the factory, the forest topsoil has the following nutrients mean values: the mean $\mathrm{pH}$ is 6.03 while the Sodium $(\mathrm{Na})$, Potassium $(\mathrm{K})$ and Magnesium $(\mathrm{Mg})$ are $14.78 \mathrm{ppm}, 37.69 \mathrm{ppm}$ and $0.68 \mathrm{cMol} / \mathrm{kg}$ respectively. At this point also, the amount of calcium (Ca) is $1.64 \mathrm{ppm}$ and the Phosphorus is $29.17 \mathrm{ppm}$. However, the level of Nitrogen $(\mathrm{N})$ at this point is $0.56 \%$, the Carbon (C) is $3.53 \%$, the Organic matter (OM) is
$6.09 \%$ and CEC is $19.60 \mathrm{cMol} / \mathrm{kg}$. The mean values for the nutrients chemical properties of forest topsoil at hundred and seventy meters, hundred and ninety meters, two hundred and ten meters, and two hundred and thirty meters away from the factory are recorded as shown in table 2. The control has the following mean values: the mean $\mathrm{pH}$ is 5.91 while the Sodium $(\mathrm{Na})$, Potassium $(\mathrm{K})$ and Magnesium $(\mathrm{Mg})$ are $11.52 \mathrm{ppm}, 23.08 \mathrm{ppm}$ and $0.32 \mathrm{cMol} / \mathrm{kg}$ respectively. At this point also, the amount of calcium $(\mathrm{Ca})$ is $1.75 \mathrm{ppm}$ and the Phosphorus is $45.05 \mathrm{ppm}$. However, the level of Nitrogen $(\mathrm{N})$ at this point is $0.47 \%$, the Carbon $(\mathrm{C})$ is $2.00 \%$, the Organic matter $(\mathrm{OM})$ is $3.45 \%$ and CEC is $24.50 \mathrm{cMol} / \mathrm{kg}$. For Transect 2, the mean $\mathrm{pH}$ at fifty meters to the cement factory is 5.61 while sodium $(\mathrm{Na})$ is $10.87 \mathrm{ppm}$. At this point also, the amount of Potassium (K) is $23.08 \mathrm{ppm}$, the magnesium $(\mathrm{Mg})$ is $0.52 \mathrm{cmol} / \mathrm{kg}$, the Calcium $(\mathrm{Ca})$ is $2.24 \mathrm{ppm}$ and phosphorus (P) is $22.71 \mathrm{ppm}$. At the same point, the level of Nitrogen $(\mathrm{N})$ is $0.63 \%$, the Carbon $(\mathrm{C})$ is $1.04 \%$, Organic Matter (OM) is $1.79 \%$ and CEC is $28 \mathrm{cmol} / \mathrm{kg}$. Seventy meters away from the factory, the forest topsoil has the following nutrients mean values: the $\mathrm{pH}$ is 5.58 while sodium $(\mathrm{Na})$ is $9.13 \mathrm{ppm}$. The amount of potassium $(\mathrm{K})$ at this point is $18.72 \mathrm{ppm}$, the Calcium (Ca) is $1.36 \mathrm{ppm}$, and Phosphorus $(\mathrm{P})$ is $24.11 \mathrm{ppm}$. Furthermore, the Nitrogen $(\mathrm{N})$ level is $0.42 \%$, the Carbon (C) is $2.77 \%$, Organic matter (OM) is 4.78 and $\mathrm{CEC}$ is $21.00 \mathrm{cmol} / \mathrm{kg}$. The nutrients mean values for the ninety meters away from the factory are: the mean $\mathrm{pH}$ is 5.97 while the Sodium $(\mathrm{Na})$ is $10 \mathrm{ppm}$. Also at this point, the Potassium $(\mathrm{K})$ is $25.64 \mathrm{ppm}$, the Magnesium $(\mathrm{Mg})$ is $0.35 \mathrm{cmol} / \mathrm{kg}$, the Calcium $(\mathrm{Ca})$ is $1.48 \mathrm{ppm}$ and Phosphorus $(\mathrm{P})$ is $14.78 \mathrm{ppm}$. The Nitrogen $(\mathrm{N})$ level at the point is $0.49 \%$, the Carbon (C) is $1.98(\%)$, Organic matter (OM) is $3.41 \%$ and $\mathrm{CEC}$ is $21 \mathrm{cMol} / \mathrm{kg}$. Hundred and ten meters away from the factory, the forest topsoil has the following nutrients mean values: the mean $\mathrm{pH}$ is 5.61 while the Sodium (Na), Potassium (K) and Magnesium $(\mathrm{Mg})$ are $11.74 \mathrm{ppm}, 27.95 \mathrm{ppm}$ and $1.28 \mathrm{cMol} / \mathrm{kg}$ respectively. 


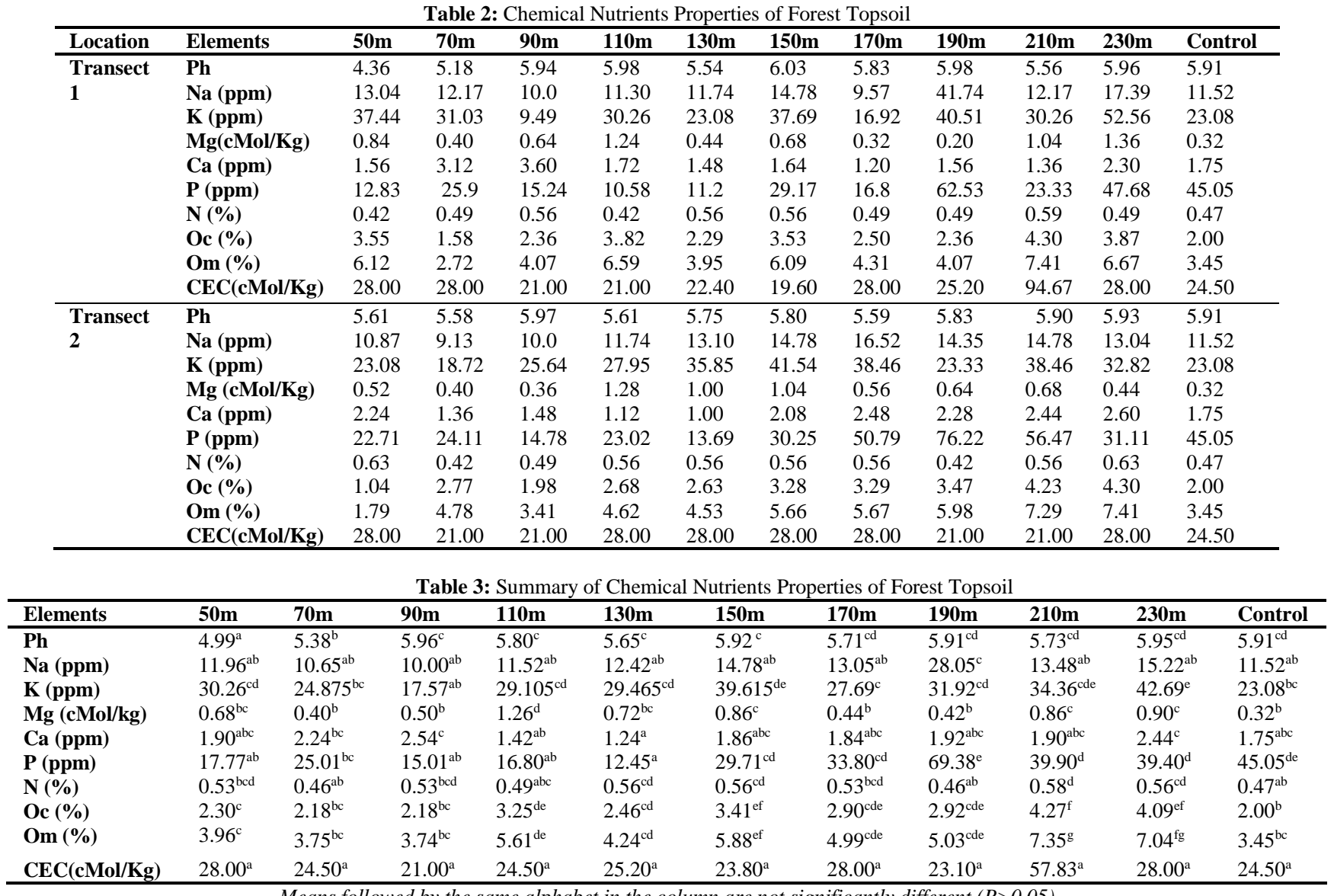

Means followed by the same alphabet in the column are not significantly different $(P>0.05)$

At this point also, the amount of calcium $(\mathrm{Ca})$ is $1.12 \mathrm{ppm}$ and the Phosphorus is $23.02 \mathrm{ppm}$. However, the level of Nitrogen $(\mathrm{N})$ at this point is $0.56 \%$, the Carbon $(\mathrm{C})$ is $2.68 \%$, the Organic matter $(\mathrm{OM})$ is $4.62 \%$ and $\mathrm{CEC}$ is $28 \mathrm{cMol} / \mathrm{kg}$. The nutrients mean values for the chemical properties of the remaining distances in meters are recorded as shown in table 2 . The control has the following nutrients mean values: the mean $\mathrm{pH}$ is 5.91 while the Sodium (Na), Potassium $(\mathrm{K})$ and Magnesium $(\mathrm{Mg})$ are $11.52 \mathrm{ppm}$, $23.08 \mathrm{ppm}$ and $0.32 \mathrm{cMol} / \mathrm{kg}$ respectively. At this point also, the amount of calcium (Ca) is $1.75 \mathrm{ppm}$ and the Phosphorus is $45.05 \mathrm{ppm}$. However, the level of Nitrogen $(\mathrm{N})$ at this point is $0.47 \%$, the Carbon $(\mathrm{C})$ is $2.00 \%$, the Organic matter (OM) is $3.45 \%$ and CEC is $24.50 \mathrm{cMol} / \mathrm{kg}$. The results of summary of chemical nutrients properties and One-way analysis of variance for comparison of chemical properties of forest topsoil at different distances away from cement factory are presented in Table 3 andTable 4.The study of physicochemical properties of topsoil around the cement factory revealed a strong influence of the particulate pollutants on the topsoil in close proximity to the cement factory. 
It was discovered that the topsoil properties; moisture content and soil $\mathrm{pH}$ varied at the distances away from the factory. There were also variations in the other soil nutrient properties; carbon, nitrogen, phosphorus, potassium, sodium, calcium, magnesium, cation exchange capacity and organic matter arising from the effect of cement dust. The cement dust particles entering the soil increased the $\mathrm{pH}$ of the soil, making it more alkaline. The highest $\mathrm{pH}$ (6.03) was observed in the hundred and fifty meters sample, indicating highest particulate pollution. Bilen (2010) reported that the soil $\mathrm{pH}$ changes are connected with content of cement dust. Cement dust affects soil pH directly, and soil acid phosphatase enzyme activity indirectly. For Transect 1, the data of soil chemical analysis as shown in Table 2 revealed that the soil $\mathrm{pH}$ moved from highly acidic to moderately or slightly acid, with a range of 4.36 to 6.03 . This is followed by hundred and ten, and hundred and ninety with the $\mathrm{pH}$ value of 5.98 and 5.98 respectively. From the summary of chemical nutrients properties of forest topsoil Table 3, other nutrients elements in Hundred and fifty meters are higher compared with the nutrients from control sample with the exception of phosphorus which is lower than the phosphorus content in the control sample. The soils are not as acidic as is typical of most soils in the area derived from acid sands of southern Nigeria (Ubi et al., 2013). The higher $\mathrm{pH}$ could be attributed to the continuous addition of cement dusts from the cement factory over the years. For Transect 2, the result of the chemical analysis showed that $\mathrm{pH}$ ranges from 5.58 to 5.97. In this transect, ninety meters in to the adjoining forest have the highest $\mathrm{pH}$ value of 5.97 while the seventy meters has the lowest $\mathrm{pH}$ value of 5.58 . The higher $\mathrm{pH}$ could as well be attributed to the continuous addition of cement dusts from the cement factory over the years. The exchangeable potassium $(\mathrm{K})$ contents for transect 1 and transect 2 ranged from 9.49 to 52.56 ppm and 18.72 to 41.54 respectively. Values less than $0.2 \mathrm{cmol} / \mathrm{kg}$ were determined to be lower than the average obtainable for other coastal plain soils (Agboola and Gorea, 1973; Adepetu et al,. 1979). It was as well discovered that the changeability in $\mathrm{K}$ content between the two transect did not follow any regular pattern (Table 2). Exchangeable magnesium $(\mathrm{Mg})$ contents for transect 1 and transect 2 ranged from 0.20 to $1.36 \mathrm{cMol} / \mathrm{kg}$ and 0.32 to 1.28 respectively. Most of these values were high because they were more than $0.3 \mathrm{mg} / \mathrm{kg}$, considered average for most Nigerian soils (Sobulo, 1999; Lombin, 1973). The Potassium (K) and Magnesium (Mg) concentration are higher in the site location samples than in the control sample. Table 2 also showed that the value of calcium content in transect 1 and transect 2 ranged from 1.2 - $3.6 \mathrm{ppm}$ and 1.00 to 1.60 respectively. The standard saturation of calcium range in soil which is acceptable by agronomists is $25-37.5 \mathrm{ppm}$. The moderate to high Ca contents of the soils in the study area might be attributed to the calcareous nature of cement dust depositions on the soil surface and not necessarily derived from the coastal sand parent materials, which are always deficient in $\mathrm{Ca}$. Available $\mathrm{P}$ content is lower in almost all the soils across the distances compared with the control except in some cases (one hundred and seventy, one hundred and ninety, two hundred and ten and two hundred and thirty) meters where the phosphorus falls below the control value. Transect 2 shows the mean ranges of available $\mathrm{P}$ to be greater than the optimum value of between 25 and 36 ppm for tropical soils (Dean and Olson, 1965) except for ninety meters and hundred and thirty meters which is rated less than the optimum. The Nitrogen and Organic carbon content were high in the samples than in the control. Organic-matter content derived from the organic carbon followed the same trend (Table 2). The values range from 1.79 to $7.41 \%$ in the soil samples and $4.35 \%$ in the control. The high organic-matter content can be as a result of increased microbial activities in the topsoil of the locations, thus resulting in the rapid rate of organic matter decomposition and incorporation into the soil. Therefore, the high organic matter content in the soils of the cement area has been attributed to the emission of cement dust to the soils, resulting in improved organic-matter cycling and plant growth.

Conclusion: The results obtained for the physical and chemical characteristics of topsoil in the study area indicated a strong influence of cement dust that settled on the forest soil. The result showed that the most of the chemicals were significantly higher in the study areas than the control. The emission of cement dust over the years was found to have contributed significantly to raising the $\mathrm{pH}$ to a range of 4.95 to 6.5 , which will likely favour plant uptake of many essential nutrients (both macro and micro) and reduce the fixation of soil phosphorus, which is a common feature of acid tropical soils. The high organic matter content in the study location samples was attributed to the addition of cement dust to the topsoil, resulting in improved organic-matter cycling and plant growth. It is established that cement dust affects the soil nutrients properties of the forest soil in close proximity to the cement factory. Although the present levels of the soil properties do not pose immediate threat to tree growth, accumulation over time can lead to greater danger.

\section{REFERENCES}

Adebiyi, A D., Adiat, KAN; Eluwole A D. (2020). Development of Empirical Models for Analysis of Subsoil Agricultural Parameters from Resistivity 
measurement in a basement of Complex terrain. NARIAG. J. Astron. Phys. 9(1):260-271

Adepetu, J A., Adebayo, AA; Aduayi, E A., and Alofe, C O. (1979). "A preliminary survey of fertility status of some soils in Ondo State under traditional cultivation". Ife J. Agric., 1: 134-149

Agboola, AA; Gorea, R B. (1973). The relationship between Soil $\mathrm{pH}$, Organic matter Available P, Exchangeable; Potassium, Calcium and nine elements in the Maize tissue soil. J. Soil. Sci.15 (1):367-375

Association of Official Analytical Chemist (1999).

Barker, J S F (2001). Conservation and Management of Genetic Diversity: Domestic animals perspective. Carrier and Technical Education

Bhojraj, T (1973): Available and Inorganic Forms of Phosphorus in selected Alfisols and Mollisels. IOWA State University Ph.D. Agronomy. Digital Reposition.

Biey, E M., Mortier, H; Willey, V (2000): Nitrogen transfer from grey municipal solid waste to high quality compost. J. Biores. Technol.73 (1):47-52

Bilen, S (2010). Effect of Cement dust Pollution on Microbial Properties and Enzyme activities in cultivated and no-till soils. Afr. J. Microb. Res. 4(22):2418-2425

Brigden, K; Santillo, D. (2002) Heavy Metal and Metalloid content of Fly ash collected from the Sual, Mual, Mauban and Masinloe Coal fired power plants in the Philippines. Technical Note. Green peace Research Laboratory, Department of Biological Science. University of Exeter, Exter, Uk.

Dean, L A. and Olson, S R. (1965) Phosphorus. In Methods of Soil Analysis; Black, C.A. (ed.): (Agronomy Series No. 9, part 2). ASA: Madison, Wisc.Pp1035-1049.

Gherghe, F. I; Barbu, I (2010).The effects of Air pollutants on Vegetation and the role of Vegetation in Reducing Atmospheric Pollution.

Heerden, PD R, Kruger, G H .J, Louw, M K. (2007). Dynamic Response of Photo system II in the Nalimb. Desert shrub, Zygophyllum prismatocarpum, during and after foliar deposition of limestone dust. J. Environ. Pollute. 146 (1):34-45.
Ibitoye, AA (2008): Laboratory manual on basic Soil analysis. Akure (Ondo State). Publish by Foladive, Nigeria Limited

Inibabi, S M., Carriga, C and Mcknna, S (2013). Trends and Developments in green cement and Concreate Technology. Inter. J. Sustain. Built Environ. 1(2):194-196.

Lombin, L.G (1979) Evaluation of the magnesium supplying powers of the Nigerian savannah soils. J. Soil Sci. Plant Nutrit. 25(4):477-492

Oyinlola, E. Y. and Chude, V. O (2010). Status of available micronutrients of the basement complex Rock- Derived Aifisols in Northern Nigeria Savannah. Tropical and Subtropical Agroecosystem 12(2):229-237. Universidad Autonoma de Yucatan Merida, Yucatan Mexico.

Pathak, M D; Khan, Z R (1994). Insect pest of Rice (4):79-85.

Rufus, S., Sunday, O. A. and Abayomi, G. D. (2012) Total and extractable Copper ion, Manganese and Zinc in Major Agricultural soils in the lower Benue Valley, Central Nigeria and the Concept of extractant efficiency. Nig. J. Chem. Res. 17: (5982).

Russel, E H (2007). Air Pollution control in the cement company Dallas, Texas pp 228-249

Samuel, AA (2012): Microbial contamination of Shea (Vitellaria paradoxa G. Don) Butter from Local Markets in the Southern and Edo States, Nigeria. Ife J. 19(2):333-339.

Sobulo, R A (1999). Fertilizers analysis and Interpretation. Ipan news,(1)1 September December pp 4. Institute of Public Analyst of Nigeria Lagos

Ubi, W., Ubi, M. W. and Akpanidiok, A. (2013) Effect of N. P. K 15:15:15 Fertilizer and Internal Management on the Chemical properties of Coastal plain sands of Akpabuyo. Nig. Global J. Agric. Sci.1 (12):73-79

Vhahangweli, M; Khathutshelo, L.M (2018). Environmental Contamination by Heavy metals. DOI: 10.5772/intechopen.76082 